\section{V． 自然計数と偽パルスを除く回路}

いままで述べたように GM カウンタやシンチレー タによる計数值は，変調パルスによる計数值のはかに パックグラウンド・パルスや㙳パルスの計数值を含ん でいる。これ除く 1 つ試みを第 5 図に示した。こ の方法は加速器など変調パルス線源のパルスとカウン タに受けられるパルスとを時一致回路で結合し，一致 したパルスのみを計数することによって，ほは完全に (11)式に従5よ5にしたるのである。

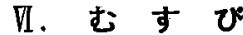

（1）本報では，加速器などから発生するパルス変調 された放射線の粒子束密度を決定する際の有效な 数え落しの式を誘尊し，これが正しいことを実験 で明らかにした。

(2) カウンタを用いる計数率の測定により，パルス 変調された放射楾の放射線強度を決定できること を GM カウンタによる実験で証明した。

以上の考察は一般に放射線強度の低いレベルの測定 が多い保健物理などの線量率測定や加速器からのパル ス変調された放射線の場合にもそのまま当てはまる。

実際にパルス変調されたX線または $\gamma$ 線のモニタや サーペイメータに使用するには，

（a）強レペルの放射線に対しては積分形の電離箱 (b) 中レベンの放射線に対 しては GM 形

(c) 低レペルの放射線に対してはシンチレータ の各検出器を使用することが便利である。 この際(b),(c)では，本文で述べた数え落しの公式を適 用し, 電離箱を 1 次測定器として較正する。一致回路 を併用すると，その測定精度の向上には一層有効であ 万5。

最後に本研究に協力された小川，山崎，谷田，岡田の 各氏に感謝するとともに本研究が行なわれたエレクト ロンライナックの建設にご援助いただた文部省， 北海道大学の関係機関および東京大学の熊谷, 西川, 宮 原, 田中の諸氏に深く感謝いたします。

（1962年 12月24日 受理）

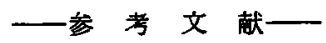

(1) A. M. CORMACK: Nucl. Inst. Meth., 15, 268 (1962).

(2) VON Droste: Z, Physik, 100, 529 (1936). 湯川秀樹, 坂田昌一：Sci. Pap. I. P.C.R., 31, 187 (1937).

G. V. Dunworth: Rev. Sci. Instruments, 11, 167 (1947).

W. K. Sinclair: Nucleonics 7. No. 6, 21 (1950).

\title{
研究論交
}

\section{1. 金属ウラン燃料の改良, (I) \\ ウランの結晶粒度に及ほす各種添加元素, 熱処理および加工の影響 \\ 丸 谷 和 夫*, 木 村丈太郎**}

Study on the Improvement of Metallic Uranium Fuel, (I)

The effects of additive elements, heat treatments and hot-rolling process to the grain size of metallic uranium

By Kazuo MARUYA and Jōtaro KIMURA

\begin{abstract}
It must be very important to find out the effective method to prevent the anisotropic growth of metallic uranium due to thermal cycling and neutron irradia-
\end{abstract}

\footnotetext{
* 三荾原子力工業(株)研究所 (Engng. and Res. Inst. of Mitsubishi Atomic Power Ind. Inc.)

** 三菱レイノルズフルミニウム（株）（Mitsubishi

Reynolds Aluminum Co. Ltd.)
} 
tion in order to achieve high burn-up of metallic uranium fuel.

The grain refinement degree of the binary and ternary alloys containing the minor additives of $\mathrm{Al}, \mathrm{Cr}, \mathrm{Fe}, \mathrm{Mo}, \mathrm{Nb}, \mathrm{Si}, \mathrm{Ti}, \mathrm{W}$ and $\mathrm{Zr}$ were studied after the appropriate heat treatments and the hot rollings.

Major experimental results were summarized as follows:

(1) There were remarkable grain refinements of uranium by the addition of $\mathrm{Cr}, \mathrm{Nb}$, Mo and $\mathrm{Zr}$ with an adequate heat treatments.

These phenomena were considered mainly due to the transformation of "Nucleation and Growth" type.

In addition to it, the change of volume on phase transformation, the delay of transformation rate on cooling or quenching, the remained stress by precipitation of another phase on tempering and the precipitation of non-metallic inclusions might have some roles on the grain refinement of uranium.

(2) The grain refinement was able to be performed appreciably by the addition of $0.2 \% \mathrm{Cr}, 0.3 \sim 0.6 \% \mathrm{Nb}, 0.5 \sim 1.0 \% \mathrm{Mo}, 1.0 \sim 2.0 \% \mathrm{Zr}$ respectively with the gamma heat treatment.

The concentration variation in the range mensioned was not notable factor to the refinement.

(3) The ternary alloys with two additives described above showed good grain refinement effect on uranium.

(4) Hot rolling process showed no effect on the grain refinement.

(5) Ternary alloys of $\mathrm{U}-\mathrm{Nb}(0.3 \sim 0.6 \%)-\mathrm{Mo}(0.3 \sim 2.0 \%)$ and $\mathrm{U}-\mathrm{Nb}(0.3 \sim 1.5 \%)$ $\mathrm{Zr}(>1 \%)$ showed the fine grain textures and good workability in hot rolling. These alloys indicate the direction of improvement of metallic uranium.

\section{I. まえがき}

金属Uの結晶粒微細化については Hayes ${ }^{(1)}$ が先駆的 な広範囲の研究を行ない，冷間加工後の $\alpha$ 焼ナ、シが るっとる効果があること，つぎに効果的なるのは $\beta$ 処 理であること, 添加物としては $\mathrm{Cr}, \mathrm{Si}, \mathrm{Zr}$ 等が有効で めること等を確認した。

また，Kalish (2) は粉末治金法により結晶粒微細化を 研究し，有彸と思われる添加元素を指摘した。

著者らは金属Uの非等方的成長を阻止するため，少 量の添加物，熱処理括よび加工を組み合わせて2元系お よび 3 元系合金の結晶粒微細化について検討を加え，
有望と目される合金の同時還元による製造, 熱サイク ル性能，耐食性などについて順次研究を進めた。

\section{II. 試料調製およひ実験方法}

\section{1. 試料の調製}

Mallinckrodt Chemical Works 社製金属Uの截片約 $20 \mathrm{~g}$ に所定量 $(0.1 \sim 3.5 \%)$ の添加元素を加え，これを タングステン電極フーク师により数回溶解チルして組 成を均一にした。

溶解䨌囲気は浄化したAガスを用いた。U拉上び各 種添加元素の分析值を Table 1 K, 添加量を Table 2 に示す。

Table 1 Analytical values of raw materials

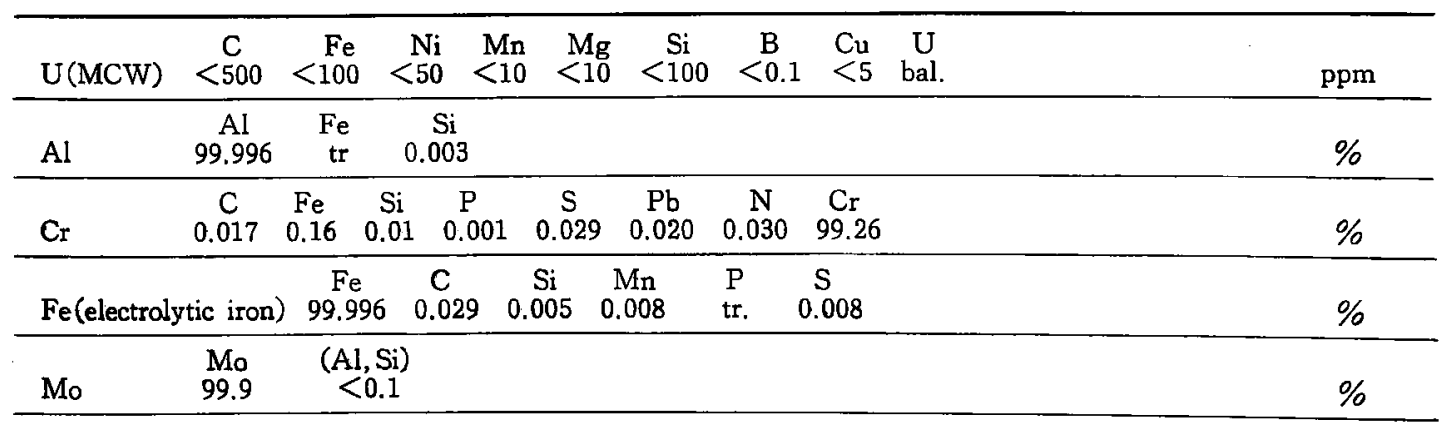




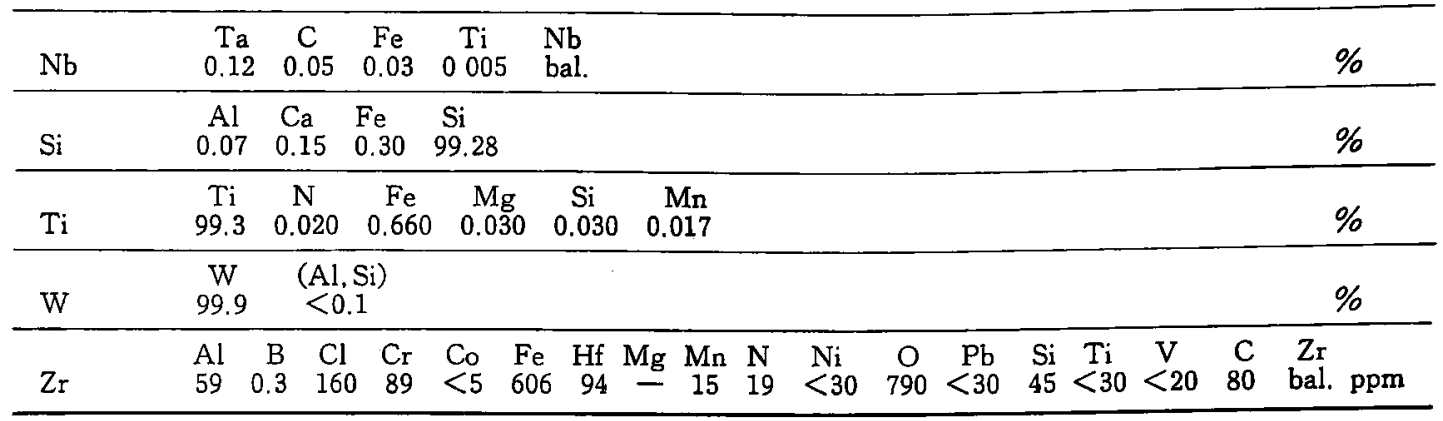

Table 2 Quantities of the additive elements

\begin{tabular}{c|c|c|c|c|c|c|c|c|c|c}
\hline \multicolumn{2}{c|}{ Additive elements } & $\mathrm{Al}$ & $\mathrm{Cr}$ & $\mathrm{Fe}$ & $\mathrm{Mo}$ & $\mathrm{Nb}$ & $\mathrm{Si}$ & $\mathrm{Ti}$ & $\mathrm{W}$ & $\mathrm{Zr}$ \\
\hline \multirow{6}{*}{} & 0.05 & - & - & - & - & - & 0 & - & - & - \\
& 0.1 & - & $\mathrm{O}$ & - & - & 0 & 0 & - & - & 0 \\
& 0.2 & - & $\mathrm{O}$ & - & - & - & - & - & - & - \\
\multirow{4}{*}{$\begin{array}{c}\text { Quantities } \\
(\%)\end{array}$} & 0.3 & 0 & - & 0 & 0 & 0 & - & 0 & 0 & 0 \\
& 0.5 & 0 & - & 0 & 0 & - & - & 0 & 0 & - \\
& 0.6 & - & - & - & 0 & 0 & - & - & - & - \\
& 1.0 & - & - & - & 0 & 0 & - & - & - & 0 \\
& 2.0 & - & - & - & 0 & 0 & - & - & - & 0 \\
& 3.0 & - & - & - & 0 & 0 & - & - & - & 0 \\
& 3.5 & - & - & - & 0 & - & - & - & - & \\
\hline
\end{tabular}

\section{2. 試料の熱処理および検鏡}

熱処理は真空炉を用いて $10^{-5} \mathrm{mmHg}$ の真空中で所 要の温度に加熱し，そのまま真空油中に落下させて焼 入れを行なった。熱処理条件はつぎのと扣りである。

$\beta$ 処理： $730^{\circ} \mathrm{C} \times 30 \mathrm{~min}$, 油焼入れ,

$$
\alpha \text { 焼ナ、シ }\left(500^{\circ} \mathrm{C} \times 2 \mathrm{hr}\right)
$$

$\gamma$ 処理 : $830^{\circ} \mathrm{C} \times 30 \mathrm{~min}$, 油烧入れ,

$$
\alpha \text { 焼ナマシ }\left(500^{\circ} \mathrm{C} \times 2 \mathrm{hr}\right)
$$

試料はすべて鏡面仕上げを行なった後クロム酸系電 解液またはエチレングリコール・リン酸系電解液にて 電解研磨を行ない，偏光顕微鏡を使用して結晶組織の

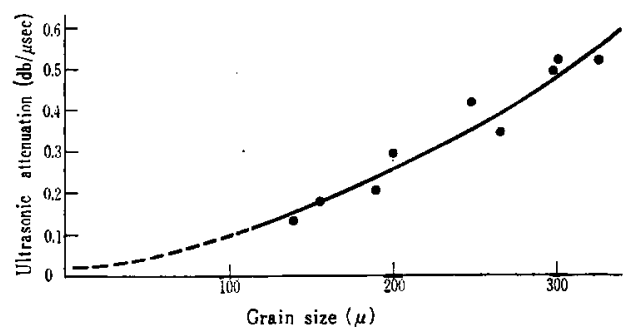

Fig. 1 Relation between ultrasonic attenuation and grain size in metallic uranium (at $15 \mathrm{M}$ cycle)

\section{観察を行なった。}

結晶粒測定は大部分 Zimmer 法を用い，粒界の不明 瞭な一部のものはめらかじめ 25 Mcycle 超音波減衰比 較装置により超音波减衰率 $(\mathrm{db} / \mu \mathrm{sec})$ と結晶粒径との 関係曲線(Fig. 1)を画きこれを検量線として大略の 結晶粒径を求めだ。

\section{而。実 験 結 果}

\section{1. 検 鏡結果}

各試料とも溶解チルの状態では金属Uと比較してほ とんど結晶粒度は変わらない(ただし，U-Mo(>0.5 W)のみは急冷凝固により $40 \sim 60 \mu$ の柆径を得るこ とが可能である。)

$\mathrm{Al}, \mathrm{Fe} 、 \mathrm{Si}, \mathrm{Ti}$ を添加したものは $\mathrm{UAl}_{2}, \mathrm{U}_{6} \mathrm{Fe}, \mathrm{U}_{8} \mathrm{Si}$, $\mathrm{UTi}_{2}$ と思われるネットワークが現われる。 以下各系について簡単にとりまとめる。

（1）天然U金属

天然U金属の結晶粒径は鋳造状態のままでは 300〜 $450 \mu$ てある(Plate 1)。これに $\beta$ 処理を施すと $200 \mu$ 前後となり， $\gamma$ 処理を施すと $150 \mu$ 前後となる。非等 方的成長を防ぐためにはランダムなく70 $\mu$ の粒径が必 要と思われるが，金属Uの場合 $\beta$ 処理を施すたけでは 微細化効果は少ない。 


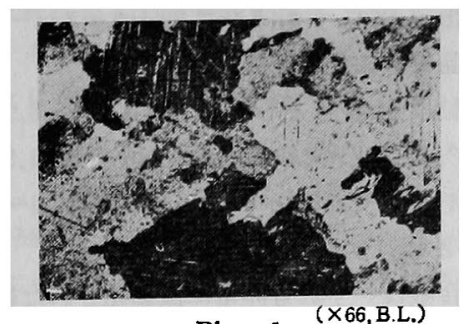

Plate 1

(2) U-Al 系合金

Plate 2 は溶解チル状態のままで現われるネットワ ーク組織である。この組織はその後の熱姏理によって る変化しない。このネットワーク部は $\mathrm{UAl}_{2}$ と見なさ れ，必ずしすマクロの結晶粒と一致しない。

Al の少量添加は結晶粒の微細化には効果が少ない。

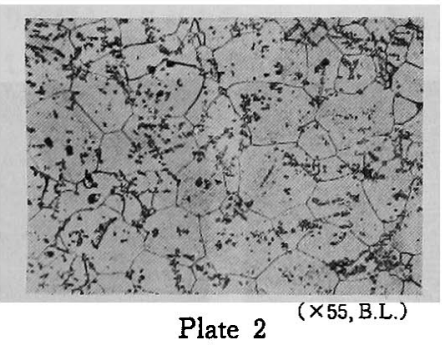

(3) $\mathrm{U}-\mathrm{Cr}$ 系合金

くりかえし $\beta$ 処理あるいは $\gamma$ 処理によって結晶粒は いちじるしく微細化され，また結晶粒の異方性も強い。

$\gamma$ 処理によって粒度が 30〜 40 $\mu$ となったものを Plate 3 に示す。Cr は元来焼入れによって $\beta$ 相を常温 にすたらす元素(3) として知られているが, 添加量が $0.1 \sim 0.2 \%$ の微量に括いてもこの效果は顕著である。 たたし，クロムを添加した場合赤熱脆性を起す傾向が 強く、熱処理時に龟裂を生ずることがある。Plate 3 中央部にも焼入れ割れが見られる。

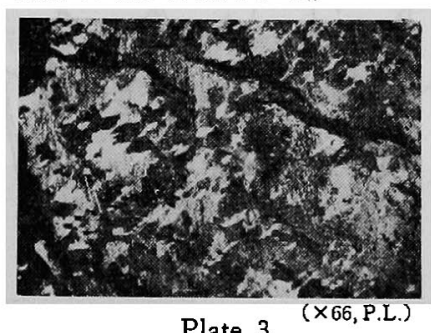

(4) U-Fe 系合金

$\mathrm{Fe}$ を添加した場合 Plate 4 に示すようなネットワ ーク組織が現われる。このネットワークは $\mathrm{U}_{6} \mathrm{Fe}$ と見 られ， $\beta$ 処理の場合にははとんど変化がないが， $\gamma$ 処 理によりこのネットワーク組織が消失して丸または角 型の異相が析出し粒界も不明瞭となる。この状況を
Plate 5 に示す。これは括そらくつぎの反応により $\gamma$ 処理に際して $\mathrm{U}_{6} \mathrm{Fe}$ が凝集するためと思われる。

$$
\alpha+\mathrm{U}_{6} \mathrm{~F} \stackrel{675^{\circ} \mathrm{C}}{\rightleftarrows} \beta+\mathrm{U}_{6} \mathrm{Fe} \stackrel{815^{\circ} \mathrm{C}}{\rightleftarrows} \gamma+\text { liquid }
$$

過剩の Fe は $\beta$ 相を保留させ，急冷により亀裂を生 じやすいと報告(4)されているが，本実験の0.5\%以下の 籁囲ではこのような現象は認められない。

$\mathrm{Fe}$ の少量添加は本実験の熱処理条件下では結晶粒 微細化効果は少ない。

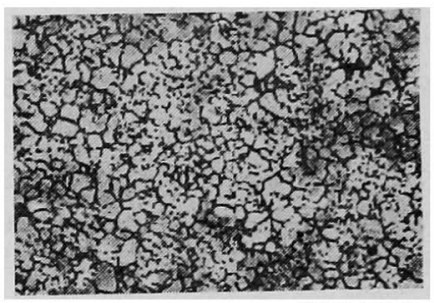

Plate 4

(X66, P.L.)

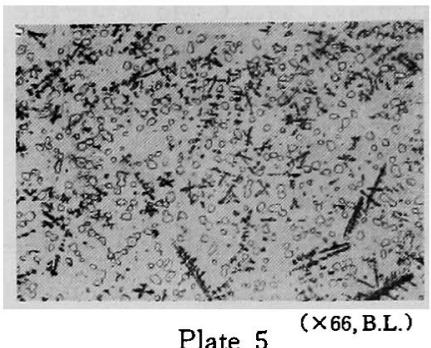

(5) U-Mo 系合金

Jepsonら (4)によると，Moを0.5\%添加した場合, 結 晶粒の微細化は表面層のみに起るとされている。しか し，本実験に扎いてはMoの結晶粒微細化に及ぼす效 果はかなり大きく，Mo0.5\%添加で〜30 $\mu$ 程度の粒度 が $\gamma$ 処理によって得られた(Plate 6)。

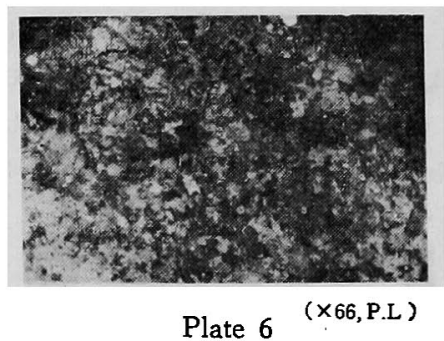

Mo 量を 1.0〜3.5\%に増加しても，熱処理時の結晶 粒度微細化には顕著な变化がなく，0.5\%よりやや効果 がある程度である。

(6) U-Nb 系合金

$\mathrm{Nb}$ は結晶粒微細化には有効な添加元素であるか， その效果は0.3\%以下ではいちじるしくない。0.6〜3\% Nb添加し $\beta$ 処理を施すと $30 \sim 50 \mu$ (Plate 7) となる。 


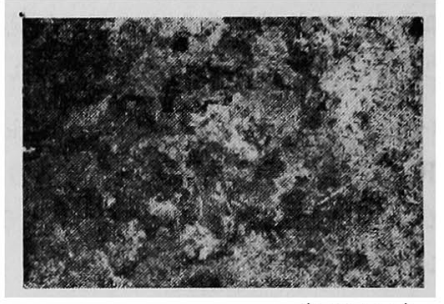

Plate 7

( $\times 66$, P.L.)
$\mathrm{Nb}$ は熱中性子吸収断面積が比較的小さく，また後 述するようにU-Nb系は加工性にも優れているので, もっとも有望な添加元素の 1 つと考えられる。

(7) U-Si 系合金

U-Si 系に打いては $\mathrm{U}_{3} \mathrm{Si}$ を燃料として使うことがか なり研究(5)されているが、ケイ素の0.05〜0.10\%程度の 少量添加は薇細化に効果は少ない。

(8) U-Ti 系合金

U-Ti 系状態図のU側はU-Mo 系のそれと類似して いるので, Ti す Mo と同㥞の微細化效果があるので はないかと予想されたが, 結果は必ずしす同粎ではな く, 微細化能はかなり小さい。

\section{（9）U-W 系合金}

Wの結晶粒微細化能力はほとんど見られない。

(10) U-Zr系

Zr2\%合金はすでに実用化されている。

Zr は添加量が $1 \%$ 以下ではあまり結晶粒を微細化 しない。1\%以上添加して $\gamma$ 処理を行な $5 と 50 \mu$ 程度 の結晶粒を得ることができる(Plate 8)。これはパーラ イトラメラに類似した組織を示しているが，X線回折 によれば Z $\mathrm{r} 1$ 〜 \%を添加して $\gamma$ 相の温度範囲より常 温に油焼入れを行なっても及相を残留しないので，本 系の変態(铰細化)機構は他のるのとは異なるすののよ うである。また，U-Zr 合金は容易に均一化しない。

$Z_{r}, \operatorname{Ti}$ は C と親和力が強いので, U中の微量（く $300 \mathrm{ppm})$ のと結合し，一部は炭化物として存在す ると考えられるが，それと結晶粒との関係はいまだ明 らかでない。

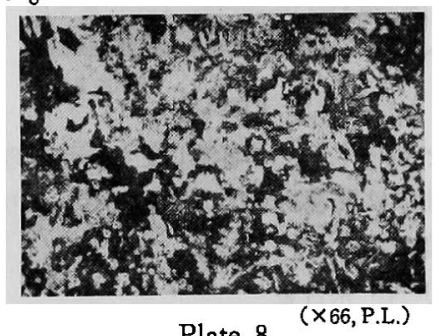

Plate 8

以上の実験結果扰よび他の諸報告(4)(6) を参考として， これらの中から結晶粒微細化に効果のある元素として
Cr, Mo, Nb, Zr をとりあげることができる。

\section{2. 結晶粒微細化 3 元系合金}

上述の結果を参考として， U-Cr(0.1〜0.5\%)-Mo $(0.5 \sim 2.0 \%), \mathrm{U}-\mathrm{Zr}(1.0 \sim 5.0 \%)-\mathrm{Nb}(0.6 \sim 1.5 \%), \mathrm{U}-$ $\mathrm{Nb}(0.6 \sim 1.5 \%)-\mathrm{Cr}(0.1 \sim 0.5 \%)$, U-Nb $(0.2 \sim 1.5 \%)-$ $\mathrm{Mo}(0.2 \sim 2.0 \%) 3$ 元系合金を試作した。

3 元系合金はいずれる非常に微細化された組織を示 し，添加元素の微細化能は 2 元系の場合よりるさらに いちじるしい。例としてつぎの 2 合金の顕微鏡組織を Plates 9,10 に示す。これらはいずれる等軸棈造であ って Nucleation-Growth 型変態により微細化したも のであることを示している。

結晶粒度は溶解チルのままで20〜 40 $\mu, \beta$ 処理後は

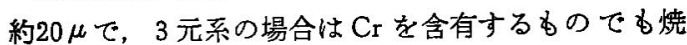
入れ割れはあまり見られなかった。

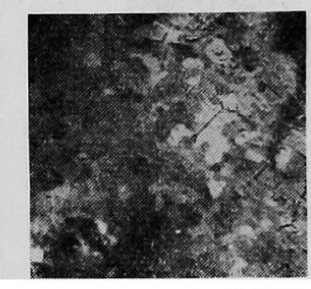

Plate 9

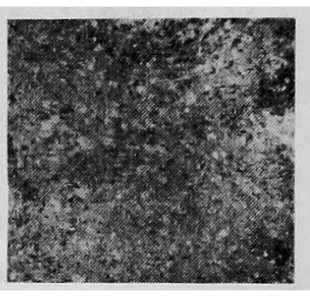

Plate 10
各熱処理過程の硬サ変化を U-Nb-Mo, U-Cr-Mo両 系について Fig. 2 に示す。

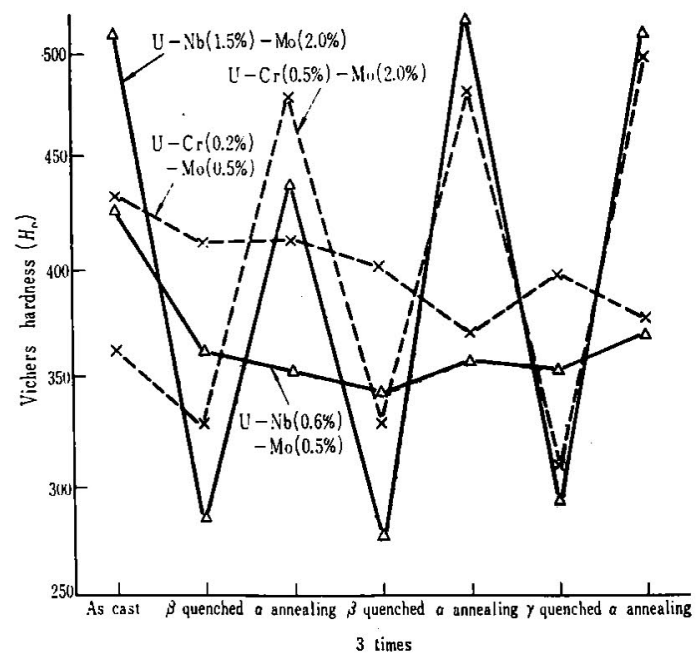

Fig. 2 Hardness of some ternary alloys after several heat treatments

試作した 3 元合金の硬サはすべて $H_{V}=300 〜 550$ で あった。

添加量のやや多い U-Nb(1.5\%)-Mo(2.0\%) および $\mathrm{U}-\mathrm{Cr}(0.5 \%)-\mathrm{Mo}(2.0 \%)$ の 2 合金は Fig. 2 に示すよ 
うに烧入れによって硬サが下がり，烧ナマシによって 上界し，その差は $H_{V} 200$ にも遳する。

これは U-Moの $\delta$ 相の析出が関与していると推定 される。

しかしこれらと同系で添加量を少なくした U-Nb $(0.6 \%)-\mathrm{Mo}(0.5 \%)$ お。び U- $\mathrm{Cr}(0.2 \%)-\mathrm{Mo}(0.5 \%)$ 㤝 Fig. 2 k示すよ5に各熱処理過程を通じて硬サ変化 ははとんどない。しかしながら，添加量の多い・前者(30 $\sim 40 \mu)$ と少ない後者( $40 \mu$ )には結晶粒度の差はほ そんど諰められず，添加量の相違は微細化に影響がな い。この現象は結晶粒微細化機構の解明上興味ある䦓 題である。

\section{3. 熱間口ール加工性}

ロール加工試料は，あらかじめ10\%の母合金をアー ク邹炕より溶製し，これを約 $600 \mathrm{~g}$ の金属U中に計算 量に配合し， $\mathrm{MgZrO}_{3}$ で被覆した黒鉛ルッボ中で真空 溶解し，黒雓鋳型飞鋳込み， $\phi=15 \mathrm{~mm}, l=100 \mathrm{~mm} \oplus$ 丸棒とした。

この丸棒の表面約 $2 \mathrm{~mm}$ を切削し，ステンレスパィ プにつめ両端に密栓をしてアーク溶接を施し，ロール 加土試料とした。

ロール機は 2 段ロール (胴長 $\left.20^{\prime \prime}, \phi 10^{\prime \prime}\right)$ ，回転 32 r.p.m., $30 \mathrm{Hp}$ のので, 用いた Calibre は SquareOval (n) 系列である。

試料はあらかじめ $600^{\circ} \mathrm{C} に$ 保持したソルトバスに入 れ，15 min 間加熱して 1 回パスするごとに $1 \mathrm{~mm}$ ず つの reduction 索与光，最䅂的には $5 \mathrm{~mm}$ 角にまで加 エした。

圧延後の試料の外見をPlate 11 に示す。Plate 11 中の合金量は配合值である。分析値を Table 3 K示 す。Cr，Al を添加した試料は熱間ロールにより破断 し， $\mathrm{Fe}$ を添加した試料はクラックが入った。 Moを添 加した試料にもへャクラックがあった。

$\mathrm{Ti}, \mathrm{Nb}, \mathrm{Zr}$ を添加した試料の外見はクラックや欠陥 が少なく良好である。結果をまとめてTable 3に示す。

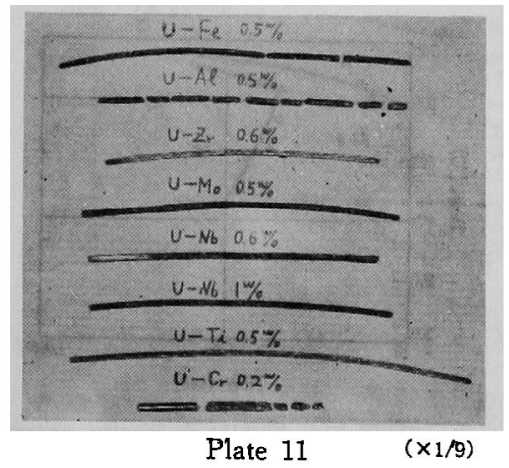

Table 3 Hot workabilities of several uranium base alloys

\begin{tabular}{c|c|c|l|c}
\hline $\begin{array}{c}\text { Speci- } \\
\text { mens }\end{array}$ & $\begin{array}{c}\text { Additive } \\
(\%)\end{array}$ & $\begin{array}{l}\text { Reduc- } \\
\text { tion } \\
(\%)\end{array}$ & $\begin{array}{l}\text { Work- } \\
\text { ability }\end{array}$ & Remarks \\
\hline $\mathrm{U}-\mathrm{Al} 1$ & 0.19 & 68.0 & Bad & $\begin{array}{l}\text { Cracked, } \\
\text { broken down }\end{array}$ \\
$\mathrm{U}-\mathrm{Cr}$ & 0.19 & 46.0 & Bad & $\begin{array}{l}\text { Cracked, } \\
\text { broken down }\end{array}$ \\
$\mathrm{U}-\mathrm{Fe}$ & 0.68 & 59.5 & Not good & Cracked \\
$\mathrm{U}-\mathrm{Mo}$ & 0.41 & 67.0 & Fair & Hair cracked \\
$\mathrm{U}-\mathrm{Nb}$ & 0.54 & 66.4 & Good & - \\
$\mathrm{U}-\mathrm{Ti}$ & 0.91 & 69.7 & & - \\
$\mathrm{U}-\mathrm{Zr}$ & 0.72 & 66.4 & Excellent & - \\
\hline
\end{tabular}

結晶粒度の点だけから見ると熱間ロール加工の影響 は梳とんどなく，前掦の各種合金の粒度と変りはな い。

4. 加工, 熱処理時の硬サ变化

各合金の熱処理過程における硬変化を Fig. 3 に 示寸。
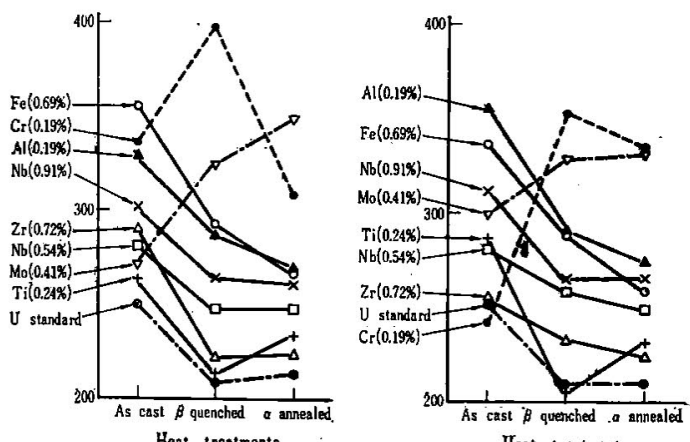

Fig. 3 Hardness of some binary uranium alloys after heat treatments Specimens were all rolled at $600^{\circ} \mathrm{C}$.

ロール加工時に重裂の発生した $\mathrm{Al}, \mathrm{Cr}, \mathrm{Fe}$ 添加試料 は圧延に上りいちじるしく硬化する。

$\mathrm{Cr}$ ，Moを添加した試料は $\beta$ 焼入れによりさらに硬 化するが，他は一様に軟化する。

$\mathrm{Cr}$ を添加した試料恃压延方向 $\left(\mathbb{H}_{7}=360\right)$ と直角方向 $\left(H_{V}=240\right)$ とではかか炕りの硬せの相異が認められる。

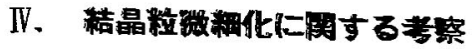

III.の夷駼結果比さり $\mathrm{Cr}, \mathrm{Nb}, \mathrm{Mo}, \mathrm{Zr}$ 等の少量添加

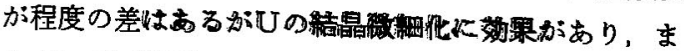
た $\mathrm{Fe}, \mathrm{Al} ， \mathrm{~W}$ 等にはとえぞ効果かないことが判明 L た。 
これらの実験事実に対する機構的解歌はU合金の $(\beta \rightarrow \alpha)$ 変態機構の解明に依存するところが多く，今 後の研究に待つべき問題であるが，現在までに得られ た結果から結晶粒微細化儿寄与すると思われる 2,3 の機構について若干の考察を行なう。

\section{1. 变態による微細化}

本実験においては微細化のすぐれたものがほとんど パーライト組織または等軸構造であって，微細化しな いるのは焼入れにおいてマルテンサイト型変態とみら れる $\alpha$ 相の粗大晶を示し，焼ナマシに扎いてさらに結 晶粒は粗大化する傾向があった。

また， $\mathrm{Mo}, \mathrm{Nb}, \mathrm{Zr}$ 等を添加した試料の結晶粒微細 化の濃度依存性は小さく，山る一定濃度以上では結晶 粒微細化の程度はあまり変わらなかった。

さらK, U-Mo(6\%), U-Nb(6\%) 両母合金の同 時還元ダービーの融解徐冷試料は他に特別の熱処理を 施さずそのままの状態でる微細結晶粒の組織(粒径約 $30 \mu)$ が観察された。

$\mathrm{U}-\mathrm{Mo}(0.5 \%)$ 合金を水冷銅製鋳型中で急冷凝固させ た場合すやはり微細化はするが，その程度は 40〜60 $\mu$ であって上述徐冷試料よりも粒径はやや大であった。

以上の事実は微細化の主要な機構がある温度範囲に 括いて生ずる Nucleation-Growth 変態であって，加 工歪がない場合はこの機構が再結晶による微細化優 先し，かつ，本実験に用いた熱処理条件の下でたまた ま Nucleation-Growth 変態をなすのに適した合金の みが微細化したことを示するのではないかと考えられ る。

\section{2. 内部䄳による再結晶核の発生}

（1）変態に括ける体積変化に伴 5 歪

金属Uの $\alpha$ (正斜方晶 $<668^{\circ} \mathrm{C}$ )， $\beta$ (複雑化正方晶 $668^{\circ}$ $\sim 772^{\circ} \mathrm{C}$ )， $\gamma$ (体心立方晶 $772^{\circ} \sim 1131^{\circ} \mathrm{C}$ (m.p.)) 各相は 結晶構造, 密度を異にするだけでなく, 結晶軸方向に上 って熱膨脹係数を異にするため, 熱処理時に $\beta \rightarrow \alpha$ (を たは $\left.\alpha^{\prime}\right)$ ，または $\gamma \rightarrow \alpha\left(\right.$ まは $\left.\alpha^{\prime \prime}\right)$ 変態における体 積変化に伴う歪が発生する。

これは Plate 12 に示すように $\beta$ 焼入れによって金

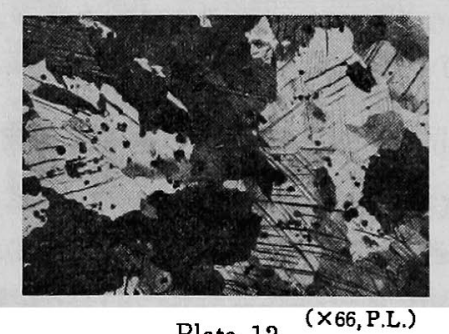

Plate 12
属Uの多角結晶中に多数の双晶を発生することによっ ても明らかである。周知のように $300^{\circ} \sim 400^{\circ} \mathrm{C} の \alpha$ 相 温度範囲内て数\%の圧縮歪を与えて $500^{\circ} \mathrm{C} \times 10 \mathrm{~min}<$ らいの焼ナマシを数回くりかえすと $30 〜 50 \mu$ 程度の結 晶粒が得られるが，これら0体積変化に伴う歪は冷間 加工において生ずる歪と同様に $\alpha$ 焼ナマシ時に再結晶 核発生を促進するものと考えられる。

金属Uあるい極微量 $(<0.1 \%)$ 添加U合金の結晶 粒微細化は主としてこの機構によると思われる。しか し，金属Uは叠拌した $\mathrm{NaOH}$ 水溶液中に $\gamma$ 相温度範 囲より焼入れても $\beta$ 相を残留せず，熱処理のみによる 効果は小さかった。

（2）変態速度の扰くれによる内部歪

$\mathrm{U}-\mathrm{Cr}$ 合金に扣いてC $\mathrm{r}$ 添加量が增加するにつれて マルテンサイト型変態の nose が低温側にずれる(3)こ とや，U-Mo 合金に批いて Mo添加量の増加ととも に $M_{8}$ 点が下がること湟等より一般に添加量を增大す ればN. G. 変態をなしうる温度範囲が増大し, 熱処理 はやりやすくなることは容易に予想されるが，その他 合金成分の增大は CCT 曲線をいちじるしく右に偏倚 させ，相対的に冷却速度を增大したことと同様の効果・ を与えるるのと考えられる。

たとえば，高純度U, U-Cr $(0.5 \%), \mathrm{U}-\mathrm{Mo}(0.5 \%)$ および $\mathrm{U}-\mathrm{Cr}(0.5 \%)-\mathrm{Mo}(0.5 \%)$ の各 TTT 曲線(4)を 比較すると Figs. 4〜7 のと找りであって，銅におけ る TTT曲線と CCT 曲楾との対応関係より類推する と，金属Uは $\beta$ 相の温度範囲よりどれ洼ど急速に燒入 れても $\beta$ 相を残留せず，M。は $\beta$ 相を保持する力が弱 く，Crはその力が大きく，さらにCrとMoを組み合 わせると, 変態時間および終了時間がいちじるしくお くれることなと゚が推定される。

$\mathrm{U}-\mathrm{Mo}(0.5 \%)-\mathrm{Nb}(0.5 \%)$ 合金を $950^{\circ} \mathrm{C}$ 上り $\mathrm{Sn}$ 浴 に焼入れた場合の TTT曲線(9) Fig. 8 に示すと拈り

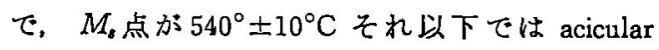
structure が現われ, $500^{\circ} \mathrm{C}$ 前後の温度で焼ナマシて

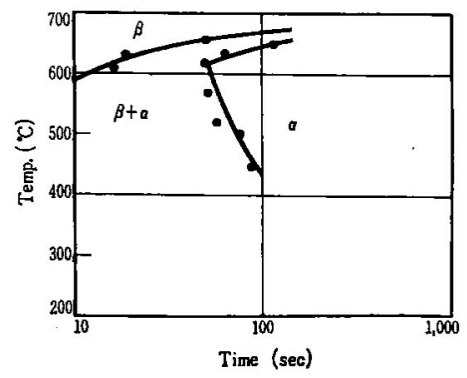

Fig. 4 TTT curve of high purity uranium 


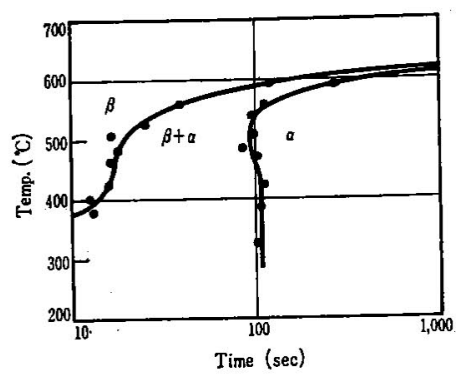

Fig. 5 TTT curve of U-Mo $(0.5 \%)$ alloy ${ }^{(4)}$

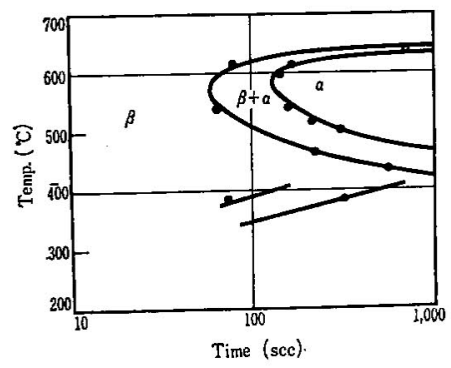

Fig. 6 TTT curve of U-Cr( $0.5 \%)$ alloy ${ }^{(4)}$

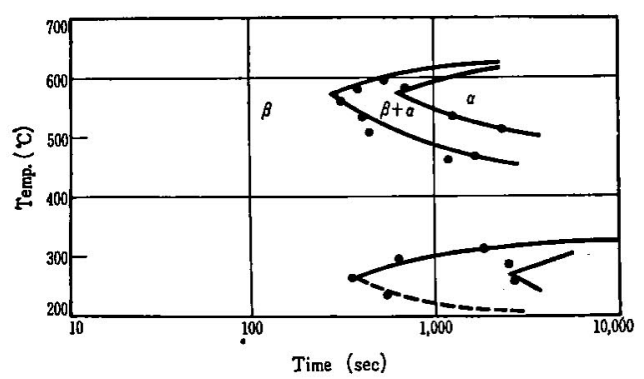

Fig. 7 TTT curve of U-Mo $(0.5 \%)-\mathrm{Cr}$ $(0.5 \%)$ alloy ${ }^{(4)}$

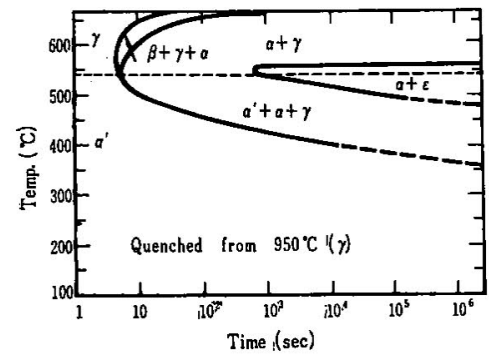

Fig. 8 TTT curve of U-0.5 $\% \mathrm{Nb}-0.5 \%$ Mo ternary alloy treated and quenched from $950^{\circ} \mathrm{C}(\gamma)^{(9)}$
ه $\alpha^{\prime}$ (Martensitic $\left.\alpha\right) \rightarrow \alpha^{\prime}+\alpha+\gamma$ なる反応が開始する のに数 sec を要することが知られている。

したがって，焼入れにおいてては 3 元系合金の方が 2 元系合金よりも， $\gamma$ 相， $\beta$ 相， $\alpha^{\prime}$ 相等をさらに多く一 層長時間残留し，岕るい性不完全変態によって内部歪 を発生させ，これらはスリップ,双晶, deformation band 等の発生を促し， $\alpha$ 焼ナマシ時に再結晶核を多 数生ぜしめる役割りを果するのと考えられる。たとえ は，本実験の U-Cr 系灿いて $\beta$ 焼入れ後の $\alpha$ 燒ナマ シによって双晶の部分から微細な結晶粒が生じている のが観察された(Plates 13，14)。

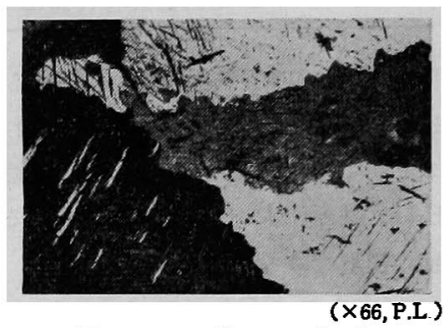

Plate $13 \quad \beta$ quenched

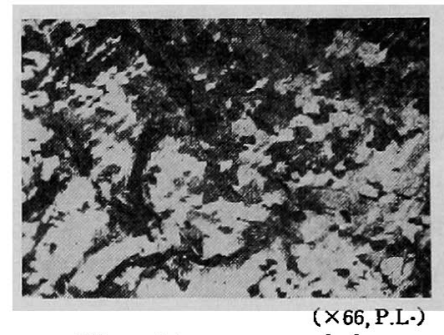

Plate $14 \alpha$ annealed

TTT 曲楾の比較上り，冷却曲楾と CCT 曲楾が交 叉しないよ5に添加量を増大したり，冷却速度を早め たりすれば微細化能は一般に高まるように推定される が，このことは 3 元系の方が 2 元系よりる微細化がい ちじるしいという本実験の結果とす大略一致する。

(3) 第 2 相の析出による歪

$\mathrm{U}-\mathrm{Nb}(1.5 \%)-\mathrm{Mo}(2.0 \%)$ と U-Cr $(0.5 \%)-\mathrm{Mo}(2.0$ W)の 2 種の合金に前述の上弓に熱処理過程における 硬変化が極めていちじるしい。すなわち， $\beta$ または $\gamma$ 烓入れによって軟化 $\left(H_{V}=300\right)$ し， $\alpha$ 焼もどしによ り $H_{V}=500$ まで硬化する(Fig. 2 参照)。

これは $\alpha^{\prime}\left(\right.$ または $\left.\alpha^{\prime \prime}\right)$ 相が $\alpha$ 相となる時の歪および 焼入れ後の $\alpha$ 焼ナマシ時に密度の小さい $\delta$ (あるいは と)相が析出するための歪により硬化するすのと考觉 られる。

$\delta$ 相の析出については $\beta$ 燒入れ, $\gamma$ 焼入れの場合は 析出せず，焼入れ後の焼ナマシの際析出することをX 線回析により確認することができた(Table 4)。 
Table 4 The confirmation of phases on some ternary uranium alloys by $X$ ray diffraction analysis

\begin{tabular}{|c|c|c|c|c|c|}
\hline \multirow{3}{*}{$\begin{array}{c}\text { Specimen } \\
\text { No. }\end{array}$} & \multirow{3}{*}{ Composition } & \multicolumn{4}{|c|}{ Results of $\mathrm{X}$ ray analysis } \\
\hline & & \multicolumn{2}{|c|}{$\beta$ treatment } & \multicolumn{2}{|c|}{$\gamma$ treatment } \\
\hline & & $\begin{array}{l}730^{\circ} \mathrm{CX} \\
30 \mathrm{~min} \\
\text { oil quench }\end{array}$ & $\begin{array}{l}500^{\circ} \mathrm{C} \times 2 \mathrm{hr} \\
\text { oil quench }\end{array}$ & $\begin{array}{c}830^{\circ} \mathrm{CX} \\
30 \mathrm{~min} \\
\text { oil quench }\end{array}$ & $\begin{array}{l}500^{\circ} \mathrm{C} \times 2 \mathrm{hr} \\
\text { oil quench }\end{array}$ \\
\hline 0 & metallic uranium & $\alpha$ & $\alpha$ & $\alpha$ & $\alpha$ \\
\hline 1 & $\mathrm{U}-0.2 \% \mathrm{Cr}-0.5 \% \mathrm{Mo}$ & $\beta+\alpha$ & $\alpha$ & $\beta+\alpha$ & $\alpha+\beta(?)$ \\
\hline 9 & $\mathrm{U}-0.6 \% \mathrm{Nb}-0.5 \% \mathrm{Mo}$ & $\alpha$ & $\alpha$ & $\alpha$ & $\alpha$ \\
\hline 10 & $\mathrm{U}-0.5 \% \mathrm{Cr}-2.0 \% \mathrm{Mo}$ & $\gamma+\alpha$ & $\alpha+\delta$ & $\gamma+\alpha$ & $\alpha+\delta$ \\
\hline 2 & $\mathrm{U}-1.5 \% \mathrm{Nb}-2.0 \% \mathrm{Mo}$ & $\gamma+\alpha$ & $\alpha+\delta$ & $\gamma+\alpha$ & $\alpha+\delta$ \\
\hline
\end{tabular}

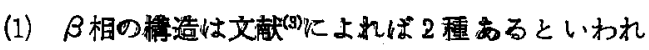

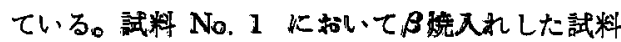

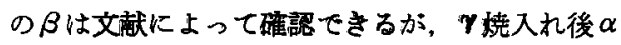

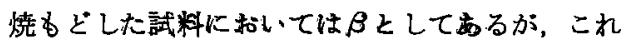
は明瞭に判別できない。

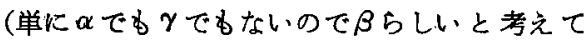
$\beta$ とした。)

(2) No. 10 および No. 2 試料学及搷入れしたもの の中の $\gamma$ 暞は $a_{0}=3.53_{B} \AA$ の b.c.c. 構造であっ た。Mo $2 \%$ 以上含む溶解急冷試料は $730^{\circ} \mathrm{C} \times$

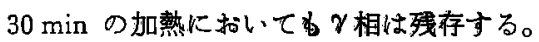

(3) $\delta$ 相 $\left(\mathrm{MO}_{5} \mathrm{U}_{11}\right)$ の存在の確認は $a=6.84 \AA, c=$ $6.55 \AA$ の正方晶構造について討算値と比較して 行なった。

（4）各相の密度はつぎのと打りである。

$$
\begin{aligned}
& \alpha: \quad 19.06 \mathrm{~g} / \mathrm{cm}^{3} \text { (室温) } \\
& \beta: \quad 18.56 \mathrm{~g} / \mathrm{cm}^{3}\left(20^{\circ} \mathrm{C}\right), \\
& \gamma: \quad 18.5 \sim 17.9 \mathrm{~g} / \mathrm{cm}^{3}\left(772^{\circ} \sim 1,132^{\circ} \mathrm{C}\right), \\
& \delta: \quad 16.57 \mathrm{~g} / \mathrm{cm}^{3} \text { (室温) }
\end{aligned}
$$

これらの現象は焼ナマシ時の変態および異相の析出 に上る体積膨脹が結晶格子に強い歪を与え，結晶粒微 細化に奇与することが考えられる。

\section{3. 非金属介在物による影響}

添加量の少ない(総星 $1 \%$ 程度) 3元系合金U-Nb (0.6 $\%)-\mathrm{Mo}(0.5 \%)$ 扎上び U-Cr $(0.2 \%)-\mathrm{Mo}(0.5 \%)$ の場 合はやや異なった挙動を示している。すなわち，各熱

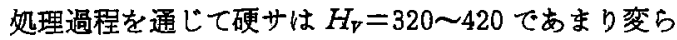
ずまたX線回折試験によっても反相の析出がおこら ない(Fig. 2, Table 4)。

しかし，結晶粒の微細化はいちじるしく $(\sim 40 \mu)$ ， 前述の $\mathrm{U}-\mathrm{Nb}(1.5 \%)-\mathrm{Mo}(2.0 \%)$ あいは $\mathrm{U}-\mathrm{Cr}(0.5$ $\%)-\mathrm{Mo}_{0}(2.0 \%)$ と同程度である。これらの3 元系合金 は $\alpha$ 焼ナマシを待たず鋳造時にすでに結晶柆は微細北
されている。このことは焼入れにおいてさえN.G. 変 態が急速に進行するか，むるいは溶製時に混入した非 金属介在物の影響によるるのと考えられる。

また，UF4 より同時還元溶製された U-Nb(0.3\%) 系合金については純度が高いためか，普通の溶解法 （母合金配合により $\mathrm{MgZrO}_{3}$ 被覆黒鉛ルッボ中で真空 溶解)によって製造した U一Nb(0.3\%) 合金に比べ結晶 粒は粗大であるが，熱処理により初めて微細化された。 以上の奏験結果を勘案すると、添加元素およびU炭 化物,酸化物, チッ化物扰よびそれらの複合体微粒子 が再結晶時の核となるか，または結晶粒界に析出し て，結晶粒の生長を妨げるであろうと推察されるが， もちろんいままでの実験範囲ではれを証明すること はできない。

電子回折により粒界における非金属介在物の存在を 確認しようと試みたが，電子線透過によって過熱され ると $10^{-6} \mathrm{mmHg}$ の雾囲気の中でる合金薄片の表面部 分が酸化するため $\mathrm{UO}_{2}$ の回折線のみが現われ，介在 物を確認するには至らなかった。

\section{4. 効果のない添加元素}

$\mathrm{Al}, \mathrm{Fe}, \mathrm{W}$ は微細化效果が小さかった。Bi 扣よび Sn も効果のないことが知られている(2)。この理由につい ては，本実験の熱処理条件および添加量の下では， N. G. 変態を生じ得ないことが主な原因と考えられ るが，その他Wを除く 4 元素は金属間化合物 $\left(\mathrm{UAl}_{2}\right.$, $\left.\mathrm{U}_{6} \mathrm{Fe}, \delta(\mathrm{UBi}) ， \delta\left(\mathrm{U}_{5} \mathrm{Sn}_{2}\right)\right)$ を形成するが，これが微粒 とはならず凝集してネットワーク(Plates 2,4)を形成 し，核生成促進效果を示さないことや，ネットワーク と結晶粒とが必ずしる一致せず，粗大化を防止できな いためではないかと考えられる。Feは結晶粒微細化 に極めて效果があるとの報告心歹あるが，本系合金の $M_{s}$ 点が低いため，本実験に適用した焼もどし温度で は微細結晶粒が再び粗大化したため微細化に奇与しな 
かったのではないかと考えられる。

Wは $\beta$ および $\alpha-U$ に対して全く固溶せず $\left(750^{\circ} \mathrm{C} 以\right.$ 下)，微細化の要因を作ることが少ないのではない と考党られる。しかしながら，WはU中のCと結合し

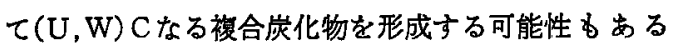
ので，どの微細化機構が主として作用するかは各元素 によって異なるようである。

\section{5. 微細化処理}

以上の推論によりつぎのよ5な微細化処理が導か れる。

（1）微細化のすぐれた合金がほとんどN. G. 変態と みられるから，各合金系(とくに 3 元系)について 最適の焼もどし温度および時間を規定する必要が ある。

（2）当然のことではあるが，焼入れ冷却速度をでき るだけ速くし内部昰を增大する。

（3）焼入れにおいて $\beta$ (または $\gamma ， \alpha^{\prime}$ )相を安定化す るような元素を加える。

（4）とくに $\beta(ま た は \gamma)$ 相Uと広範囲な固溶体を形 成し， $\alpha$ 相Uには溶解度の少ない元素がよい。

（5）上述のような元素を単独で加えるよりは，2つ 以上組み合わせた方がより効果的である。

（6）添加量は多い方が熱処理はやりやすいが，最低 限 $\alpha-U$ 八の固溶限以上が必要であろう。

熱間ロール加工, 熱間スエージ加工は微細化にはあ まり効果が期待できない。

$K_{\text {alish }}^{(2)}$ は -325 mesh のU粉末を用いて粉末治金 法に上る金属U燃料の作製法を研究した。彼は試料を 高密度にして，しかも結晶粒を粗大化しない有効な添 加元素として Mo, Nb, Si, Cr, Zr, Vを推奖し，効果の ない添加元素として Bi, Al, Sn, Fe の 4 元素を指定し た。この結果は著者らの溶解治金法に上る 2 元合金の それと大略一致する。

ただし，Kalish はもっとも有効な添加量としてMo 1 4\%, Nb 1 4\%, Zr は 2\%と中户多目の量を指定し ているが，これは試料に $\beta$ (または $\gamma)$ 熱処理を施さな かったためであろ5。

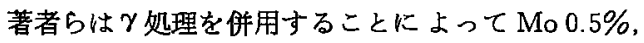
$\mathrm{Nb} 0.3 \%, \mathrm{Zr}>1 \%, \mathrm{Cr} 0.2 \% て ゙$ 充分微細化の目的を達 成し得ることを確認した。

\section{V. 結 論}

以上の結果を要約すると，つぎのとおりである。

（1）本実験の熱姏理条件 $\left(830^{\circ} \mathrm{C} \times 30 \mathrm{~min}\right.$ 油狫入れ， $500^{\circ} \mathrm{C} \times$ 2hr 㜔ナマジ)下では $\mathrm{Cr}, \mathrm{Nb}, \mathrm{Mo}, \mathrm{Zr}$ はいずれす結晶
粒微細化にいちじるしい效果があった。これらは いずれす N.G. 変態によるすのと考えられる。

(2) $\gamma$ 処理を併用すれば 2 元系の場合 $\mathrm{Cr}$ 約 $0.2 \%$,

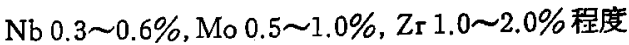
の添加蕫で結晶粒度を $\beta$ 処理金属Uの $1 / 3 \sim 1 / 10$ に微細化することができる。たたし，濃度変化は 結晶粒微細化に大きな影響を与えない。

（3）上述添加元素を組み合わせて 3 元系合金とした 場合の結晶粒の微細化はさらにいちじるしくな る。

（4）熱間ロール，熱間スエージ加工は結晶粒度には とんど影響を及ばさない。

（5）結晶粒微細化についてはN. G. 変態のほかに変 態に括ける体積変化, 変態速度の扰くれ，第 2 相の 析出等による各種の内部歪, 非金属介在物の析出 等が多少寄与をなしているすのと推定した。

(6) とくに, U- $\mathrm{Nb}(0.3 \sim 1.0 \%)-\mathrm{Mo}(0.3 \sim 2.0 \%)$ 拉 よび U-Nb(0.3〜1.0\%)-Zr $(>1 \%)$ の 2 種の 3 元 合金は結晶粒度が小さく，熱間加工性も良好なの て，金属U燃料の改良の方向を示するのと思われ る。

また, U-Cr $(0.2 \%)-\mathrm{Mo}(0.5 \%)$ 合金はロール加 工性はよくないが微細化能がすぐれており，鋳造 法または押出し法を用いれば使用可能となると思 われる。

三菱原子力工業(株)研究所長 大井上博博士は本研 究の公表を許可せられた。東北大学教授晟藤恒三博士 前所長付新実計三博士扣よび材料第二研究室長関義辰 博士は本報の校閲を賜わり，原研川崎正之博士は熱間 ロールの借用について便宜を与えられた。X楾回折に ついては鈴木国雄研究員，試料作製には広川進氏のご 協力を仰いだ。

以上の諸氏に対じ，著者らはここに深甚なる謝意を 表する。

〔1959年 2 月第 3 回原子カンンポジゥム,1960年第 1 回原子力研究総合発表会にて発表】

(1962年 7 月27日 受理)

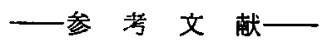

(1) E. E. Hayes: Paris' Conf. on Fuel Element, Ses. II , Natural-uranium Metallic Fuel Elements, (1957).

(2) H. S. Kalish: Trans. A.S.M., 51, 736 (1959).

(3) A. N. Holden: "Physical Metallurgy of Uranium", (1958), Addison-Wesley Publ. Co., 
Inc.

(4) M. D. Jepson, R. B. KehoE, R. W. Nichols, G. F. Slattery: A/Conf., 15/P/27, (May, 15 1958), United Kingdom.

(5) R. K. MCGEARY, et al.: Contract AT-11-1GEN-14, (Apr. 25, 1955).

(6) R. A. Noland, J. F. Schumar, J. H. Kittel:
Nucleonics, 16, 89 (1958).

(7) 川崎正之, 武谷清昭, 佐↔木吉方, 山本達郎：本誌， 1, No. 1, 19 (1959).

（8）川崎正之, 長崎隆吉, 板垣元雄, 竹村達也 : 同上, 2, No. 3, 136 (1960).

(9) E. G. ZuKas : Trans. A.S.M., 52, 797 (1960).

tod)添野浩：日立評論，44，452（1962）.

\title{
研究論交
}

\section{U-Fe 系合金の相変龍亡熱処理, ( I )}

\author{
添 野 浩*
}

Phase Change and Heat Treatment of U-Fe Alloys, (I)

By Kō SOENO

\begin{abstract}
A series of uranium alloys varying in iron content $0.5 \sim 1.0 \%$ was quenched into water from various $\beta$ - and $\gamma$-phase temperatures. Dilatation curves were determined by heating quenched specimens to obtain informations about the retention. of $\beta$ and $\gamma$ uranium. According to the results obtained, $\gamma$-to- $\beta$ transformation is not interrupted by quenching, but $\beta$-uranium is retained in metastable state at room temperature. On the case of heating the quenched specimens, retained $\beta$-uranium transforms to $\alpha$-uranium, but the martensitic transformation becomes more sluggish with increasing iron content. In $\gamma$ quenched $U-1.0 \% \mathrm{Fe}$ alloy, most of retained $\beta$-uranium transforms in nucleation and growth mechanism, of which activation energy is $43.0 \mathrm{kcal} / \mathrm{g}$-atom.
\end{abstract}

\section{緒言}

本報は, $\mathrm{U} に \mathrm{Fe}$ を約 1 \% 以下添加した U-Fe 系合 金の $\gamma \rightarrow \beta$ よび $\beta \rightarrow \alpha$ 変態の諸性質を研究した結果 の一部であるが，このような合金の相変態について は従来わずかしか知られていない。すなわち，Jepson

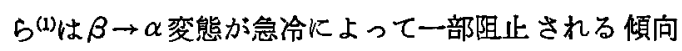
があることを指摘し，またU-0.25\% Fe 合金について かなり複雑な TTT 曲線を示しているが, 変態機棈に ついてはなんら触れていない。 Geiger ら(2)はU$0.16 \%$ (約 $0.68 \%$ ) 合金を $1,000^{\circ} \mathrm{C}$ から油冷したるのの

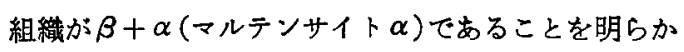
にしこれを種ょの速度で加熱した場合の焼戻し変態 を dilatometric に研究している。Fig. 1 がその結果 で,低温側の収縮はマルテンサイト型変態(以下M型変
態と略称)によって $\beta \rightarrow \alpha$ が進行するためのめので， 加熱速度を大きくするとおこりにくくなり，高温側の 収縮は成分元素の拡散を伴 5 いわゆる Nucleation and Growth 型変態(以下 N.G. 型変態と略称)によるるの とされている。すなわち, U-Fe 系合金においても $\beta$ $\rightarrow \alpha$ 変態機構にM型および N.G. 型の 2 種があること が示されているが, Geiger らの研究は $1 \%$ 以上の $\mathrm{Fe}$ を含む合金に重点がおかかているるため,U-0.16\% Fe合 金の相変態についてはあまり詳しい検討を行なってい ない。最近 Delaplace ${ }^{(5)}$ は U-0.34\% Fe 合金を $\gamma$ 相か ら種々の速度で冷却 $\mathrm{L}, \gamma \rightarrow \beta$ および $\beta \rightarrow \alpha$ 変態温度 と冷却速度との関係を明らかにしているが、いずれる あまりいちじるしい降下は認められないようである。

* 日立製作所 日立研究所 (Hitachi Ltd., Hitachi Res. Lab.) 